Meta

Journal des traducteurs

Translators' Journal

\title{
Making Words Sing and Dance: Sense, Style and Sound in Yoruba Prose Translation
}

\section{Pamela J. Olubunmi Smith}

Volume 46, numéro 4, décembre 2001

URI : https://id.erudit.org/iderudit/004197ar

DOI : https://doi.org/10.7202/004197ar

Aller au sommaire du numéro

Éditeur(s)

Les Presses de l'Université de Montréal

ISSN

0026-0452 (imprimé)

1492-1421 (numérique)

Découvrir la revue

Citer cette note

Olubunmi Smith, P. J. (2001). Making Words Sing and Dance: Sense, Style and Sound in Yoruba Prose Translation. Meta, 46(4), 744-751.

https://doi.org/10.7202/004197ar

\section{Résumé de l'article}

D'habitude, en traduction de la prose, le rythme n'a pas une grande importance pour le traducteur. Contrairement à la poésie, qui possède une forme rigide, la prose permet une forme fluide libre, donnant au traducteur une certaine liberté prosaïque. Cependant, dans des textes où la sonorité linguistique est prépondérante, par exemple le roman yoruba de D.O. Fagunwa, le traducteur doit être toujours conscient des relations entre la valeur esthétique des sons et de la signification cognitive du texte. 


\section{Making Words Sing and Dance: Sense, Style and Sound in Yoruba Prose Translation}

\author{
"ki itan mi baa dun bi oyin" \\ (that my story may be as sweet as honey [delightful, \\ well told]"1

\section{RÉSUMÉ} \\ D'habitude, en traduction de la prose, le rythme \\ n'a pas une grande importance pour le traduc- \\ teur. Contrairement à la poésie, qui possède une \\ forme rigide, la prose permet une forme fluide \\ libre, donnant au traducteur une certaine liberté \\ prosaïque. Cependant, dans des textes où la \\ sonorité linguistique est prépondérante, par \\ exemple le roman yoruba de D.O. Fagunwa, le \\ traducteur doit être toujours conscient des rela- \\ tions entre la valeur esthétique des sons et de la \\ signification cognitive du texte.
}

\section{ABSTRACT}

Ordinarily in prose translation, rhythm is usually not a matter of great concern for the translator. Unlike poetry, with its comparatively rigid form, prose, by its very nature, permits a free form fluidity, giving the translator a certain kind of carte blanche "prosaic" license. However, in languagedriven texts, as is the case in the novels of Yoruba creative writer D.O. Fagunwa, the translator has to be ever mindful of the author's purposeful inter-linking of the aesthetic value of sound to the cognitive meaning of the text.

\section{MOTS-CLÉS/KEYWORDS}

language-driven texts, prose translation, rythm, sounds, yoruba

Concern with sound in translation, usually, is with poetry. Because the translator is too well aware of the "one-language-replacing-another-language" translation process, he or she could perhaps breath easier when translating prose which, by its very nature, permits a kind of free form fluidity, giving an almost carte blanche "prosaic" license that poetry's comparatively rigid form would almost consider barbaric. From that point of view, the concern with sound as a central issue in prose translation is debatable. However, with semantic translation the aesthetic and metaphoric values of sound as well as those of structure and metaphor, are critical. In this case the prose translator would be more concerned about the more central issue of faithfulness to the sense, authorial intent, and meaning of the prose text rather than with rhythm. Unless, perhaps, the prose text author specifically indicates his or her preoccupation with sound/ rhythm; in which case, sound, as an aesthetic value, would be inextricably tied to cognitive meaning. Such is the case with Yoruba fiction writer, D.O. Fagunwa.

Known throughout Yorubaland as the father of the Yoruba novel, pioneer writer, D.O. Fagunwa blazed the trail for creative writing in Yoruba with five seminal works, ${ }^{2}$ classics in their own right, leaving a literary legacy still preeminent today. Responding early to the need for a literature for the growing literate shortly after the language was orthographed, Fagunwa soon distinguished himself not only as the purveyor of Yoruba culture but also as the consummate story teller whose gift for fusing sound with action in his adventure stories pushed the boundaries of Yoruba language. Crit$\mathrm{ics}^{3}$ and readers consistently point to the latterhis love and mastery of the language-as his distinctive claim to literary genius.

In speaking about Fagunwa's works (although scripted), we must emphasize at the outset that the distinction usually made between oral and written literature in African literary criticism obtains only in a very limited literal sense, and only when strictly applied. Because African writers writing in mother tongue or in European languages cull materials for their imaginative works from their African experiences and indigenous surroundings through a "transcreative" 4 process, we must note, as Ruth Finnigan, Ayo Bamgbose, and a host of African writers themselves have concluded, that any rigid distinction between the oral and written African literatures is arbitrary, simply one of convenience. The structure of Fagunwa's tales and those of his successors attests to this. African writers 
share a common ethnic backcloth and "drink" from a common literary wellspring, colored by the common historical, social, religious, economic and political experiences peculiar to their respective indigenous cultures.

Fagunwa's prose writing is audience-conscious, audience-driven and language-driven. In Fagunwa's works, sound is an integral part of meaning; sound, in some cases, advances meaning to the extent that sound, in such cases, is indeed meaning. For example, Fagunwa's very act of serializing the telling and recording of his tales speaks to the import of the tales' messages and the mode of their delivery. The audience of the animated Yoruba forest of Fagunwa's novels ${ }^{5}$ is enjoined to "hear" the message, "enjoy" the telling, "extract" wisdom from "hearing" the message, and indeed, eventually "broadcast" the stories and the morals "heard and learned" therein.

Thus, with clear authorial intent on the one hand and the evident rhythmic nature of Yoruba, the tonal language in which he chose to write on the other, the translator of Fagunwa's prose fiction faces the challenging task of transforming sound and meaning. It is perhaps the major challenge the translator of Yoruba language faces as the examples cited in this essay will show.

Yoruba is a tonal language, one in which intonation is so critical to the understanding of the spoken language that linguists and literary critics have described it as a "musical language." Ethnomusicologist, Akin Euba (1975), perhaps best delineates this acclaimed linguistic feature:

[...] the semantic function of Yoruba speech tones result in an active movement between the three tone levels of the language, producing in turn a high degree of sub-musical activity. The margin between this degree of sub-musical activity and what could be construed as real musical activity is so small that Yoruba speech may be regarded as lying just outside the periphery of music... The spoken art of the Yoruba commonly referred to as poetry utilizes, among other artistic means, an elaboration of the musical properties inherent in the language (476).

Thus, the linguistic, aesthetic and cultural value of sound in Yoruba literary and spoken art cannot be overlooked in translation. Consequently, knowledge of the formulation of sound patterns in both the source language (SL) and target language (TL) is crucial for the translator of Yoruba language literature because s/he discovers early that in a highly tonal SL like Yoruba, every speaker is literally a potential "poet," a weaver of rich, elaborate sound patterns. Yoruba is a language reputed for its pen- chant for tonal and semantic double-play and thus does not readily yield itself to the rhythmic patterns of a less tonal TL such as English. The seriousness with which one could make this claim lies in a simpler, more generally accepted claim by the Yoruba themselves and by non-Yoruba linguists and critics: the Yoruba's sheer love of rhetoric. Yoruba contemporary writer, Akinwumi Isola (1976) is unequivocal on this point:

This love of rhetoric, this preoccupation with beautiful words, this delight in verbal celebration, is a feature of the Yoruba novel today (473).

It is this collective cultural response to language use and the manipulation of its characteristics that the German-born, Yoruba-speaking critic, Ulli Beier (1967), delineated in one of the earliest comments about Fagunwa's literary genius:

The true Yoruba flavour of Fagunwa's work lies not in the material he used, but in the language, in the manner and tone of his story-telling. These are the elements to which the average Yoruba reader responds with delight: for Fagunwa has the humour, the rhetoric, the word play, the bizarre imagery that Yorubas like and appreciate in the language (189).

The common practice of hiring professional

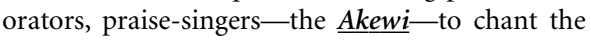
celebrants' oriki ${ }^{6}$ at important occasions such as marriage, child-naming, burial, and house-warming ceremonies provides a concrete example of this "true Yoruba flavour" Beier and Yoruba linguists and critics have noted ${ }^{7}$. This delight of the Yoruba in rhetoric calls to mind a similar value in sociopolitical discourse: the art/gift of speaking as the hallmark of Igbo oratory. As with the Igbo saying, "Proverbs are the palm-oil with which words are eaten," 8 so also the delineating essence of the Yoruba master proverb, “Owe l'esin oro, b'oro ba so $n u$, owe l'afi $i$ wa a (proverbs are the horses of conversation; when a conversation begins to flag, we revive it with a proverb).” In other words, Yorubas like and take pride in the verbal adroitness which the language, with its drum-like rhythm, presents. This would explain a storyteller's injunction to his/her audience "...ki itan mi baa dun bi oyin" (...that my story may be as sweet as honey-that is, interesting [in content], well told [in performance/presentation]); or perhaps the simple, evaluative statement, "ere naa dun", which an audience makes, indicating that the play was sweetthat is, interesting, well performed.

While every Yoruba speaker is certainly not an adept spinner of proverbial, metaphoric, quo- 
tidian language, especially the 1980s and 1990s generation, whose "YoruEnglese" is evolving daily, yet, on the tongues of the adroit/creative, the facile weaving of declamatory speech, hyperbolic language, metaphors, proverbs and ideophones, can produce a creativeness, an inventiveness that is pure music to the ears. The following example, in this case a string of proverbs used to effect poignancy, is illustrative:

Okere ti gun ori iroko, oju olode wa da... Sugbon kini a le fi be eni ti ikooko pa iya re je? Se ka so pe bee ni ikooko maa nse ni, abi k'a pe k'o mu suuru yio tun ni iya miran? Babalawo oke ohun, nwon ko o n'Ifa, nwon gba a l'obinrin. Opele ti iba ri pada ba, aja gbe e. "E ba mi mu un, e ba mi mu un," aja ko si kanga. Ile ti o pada si ile gbina. Ewo l'oku. (Aja L'o Leru, 56)

The squirrel has climbed high atop the iroko tree, the hunter's lost all hope... But how do we console the man whose mother has been devoured by a wolf? Do we say, "Well, not surprising, that's a wolf for you!" or do we tell him to be patient and take heart, he can always have another mother? It is like the Ifa priest just down the road whose Ifa oracle was seized and his wife abducted. His divination chain, the only remaining possession he could fall back on, is grabbed by an errant dog. Reactively, he gives chase, yelling, "help me catch it! Help me catch it!” But promptly, dog and chain fall into a well. Then, as if to rub salt into the wound, he decides to return home only to find it engulfed in flames. Tell me, what's left to do? (My translation).

The string of proverbs about hope/hopelessness combine effectively with the analogy about the Ifa priest's plight to drive the point home. The gravity of the situation is not lost on the listener. Simply, the rhetorical question at the end drives home the point/moral that if a mere, elusive squirrel constitutes adversity and hopelessness, then the depressed hunter needs some hard and fast lessons on the hard knocks of life from those in the know like "the Ifa priest just down the road." Even in the context of the above example in which human responses to life's curve balls run the gamut of senseless reactivity to quiet, "it's-the-will-of-the-gods" apathy, the proverb speaks, though minimized in translation. The conjuring effect of the counterpointing zenith-nadir imagery of a fortuitous squirrel, perched atop the high, unreachable branches of the tall iroko tree (itself a symbol of towering strength and hope) and a divination-chain-toting dog drowning in a well, contrasts vividly with the image of a frustrated, defeated hunter and a confused, demoralized Ifa priest. Ironically, neither men live up to the expected image of their trade. The vivid, pictorial language of the proverb appropriately combines imagery with the softer, less explosive, contemplative sounds to capture the pensive mood of the passage. The meaning of the exacting message is simply, "Enough's said!” In the case of the above example, word order and phrasing combine with sound to create mounting tension and meaning.

Or, consider an often-quoted example of repetition, one among many of Fagunwa's para-linguistic modes of effecting sound and the linguistic virtuosity for which he is acclaimed:

Bi baba ti o bi o tile ju baba elomiran, sibe baba ti o bi o ko ju baba ti o bi mi, nitorinaa jowo jeki nmo baba ti o tobi naa ti o je baba ti o bi o. Baba ti o bi emi yi ni Akowediran, baba Akowediran si ni Idakeroro-ode, Idakeroro-ode to baba fun emi Olowo-aiye, nitorinaa ko si baba ti o je baba ti o tobi ju baba ti o bi mi, nitorinaa emi be o tokantokan, masai jeki nmo baba ti o tobi naa ti o je baba ti o bi o. (Igbo Olodumare, 67-68)

Even if the father that begat you is greater than other people's father(s), still the father that begat you is not greater than the father that begat me, therefore, please let me know the father that great father who is the father that begat you. The father that begat me myself is Akowediran; the father of Akowediran is Idakeroro-ode; Idakeroro-ode is worthy to be father to Akowediran; Akowediran is worthy to be father to me Olowo-aiye. Therefore there is no father that is a greater father than the father that begat me, therefore I implore you, please let me know that great father who is the father that begat you. (My literal translation and emphasis-made purposely for effect and illustration).

"Father that begat," ad nauseam? Perhaps not! The intent of the original is to dazzle. The point: to settle the crucial question of genealogy, birthright and personhood. Note therefore the recurrent " $b i$ baba/baba $t i$ " and the " $b i \underline{o} / b i m i$ " sound combination of the Yoruba necessarily translated with the archaic "begat" in order to capture some of the intended rhythm of the Yoruba baba (repeated fifteen times for sheer effect) but which becomes totally lost and ineffective when rendered as "father" in English-the softer " $\mathrm{f}$ " having replaced the explosive "b" sound. Also note the effect of punctuation in the Yoruba and its English translation: the string of six consecutive phrases, separated by commas in the Yoruba, shows off the narrator/author's verbal dexterity. The intended onomatopoeic effect of the six-line sentence, "Baba 
ti o bi emi...baba ti o bi o" is sustained in successive "b," "j" and " $t$ " explosives, tempered minimally by a few scattered “o/으" sounds-a delightful verbal challenge to the reader/listener. Naturally, the rhythmic effects are lost in the translation, producing nothing but a string of comma splices or run-ons in English if translated literally. This loss is reflected more so in a more refined, meaning- and sense-oriented translation of the same passage:

Although it may indeed be true that your father is the greatest father of all, I must tell you that your father could not possibly be greater than my father; therefore, will you please tell me who this great father of yours is. My father is Akowediran, whose father is Idakeroro-ode, the one worthy enough to be father to Akowediran, who is worthy enough to be father to me, olowo-aiye. This being the case, there can be no father greater than the one who fathered me. Therefore, I implore you, tell me who is this greater-than-all father who is your father. (My translation-The Forest of the Almighty, 123)

This penchant for the music and wit of words and their repetition simply for their sound and meaning effect is a characteristic feature of Fagunwa, a feature Yoruba writers consider prominent and therefore aspire to achieve. As Bamgbose observes, repetition for the sake of sound is a standard with Fagunwa and Yoruba writers generally:

Sometimes the emphasis of the repetition is on the sound alone...Sometimes the repetition of words is matched with the repetition of sounds as in drum beats...Fagunwa captures the rhythm and atmosphere of drum language, and makes the repetition more natural (109).

In the example cited above, color and flavor are paramount, as are humor and the intense, drumlike, mounting rhythm which tongue-twisting repetitions can produce. As Beier aptly observed, in the hands of a master rhetorician, a word-spinning expert like Fagunwa hardly misses the opportunity to dazzle, to make words sing and dance:

He impresses the reader with his knowledge of classical Yoruba ('deep Yoruba' as the phrase goes) and he is as knowledgeable in proverbial expressions as an old oracle priest. Yet he is not content with that: he uses the language creatively and inventively, constantly adding to the traditional stock of imagery and enriching the language (189) (My emphasis.)

As I have argued elsewhere ${ }^{10}$, Fagunwa's emphasis is on the element of story as it entertains and edifies. Consequently, by exploiting those phono-aesthetic devices characteristic of Yoruba speech patterns he favored and inevitably fashioned a literary structure which fuses action with sound. This fictive model which combines excessive imagery, declamatory speech and onomatopoeia allows entertainment and moral message to intertwine. Gifted literary entertainer and moralist that he was, he exploited this complex mix of traditional narrative conventions with much aplomb in his prose writing, thus creating what today is often referred to as the Fagunwa tradition. Contemporary Yoruba writers, among them Akinwumi Isola, Adebayo Faleti, Femi Fatoba, are noted for their use and honing of some of the tested qualities of this tradition.

As Dan Izevbaye (1995) noted, Fagunwa's texts are characterized by a grand design-a pervasive, conscious architectural design to delight the eyes, stimulate the ears and challenge the mind. Like picture-stories their design and effect make them as much auditory as they are visual and graphic, imbuing them with a quality of oral performance. Based on his often reiterated authorial intent to "edify and entertain," it could be argued that this is an implicit intent on Fagunwa's part. Consequently, the Fagunwa translator faces a dilemma at the outset: sound for its sheer beauty and charm, and sound fused with action to convey the vivid sense of event and meaning. Contemporary Nigerian writer, Wole Soyinka was quick to point this out from his experience of translating ${ }^{11}$ Fagunwa, his predecessor and acclaimed influence.

Although Fagunwa did not deliberately compose poetry or include songs and chants in his fiction to achieve poetic prose as is the trend in the works of a number of contemporary Yoruba creative writers, his skillful use of proverbs, metaphors, hyperbole, ideophones and a carefully designed narrative technique which combines the first person narrative, the dream device, the story within the story and the cross reference (Bamgbose, 101) are what make his style unsurpassed and his sensibility remarkable.

The following example is illustrative:

Akara-ogun ni mi nitoto, onisegun ni baba ti o bi mi ise, babalawo si ni pelu, ogun kun inu ile wa de $\underline{e} n u$, beni nkan abami mbe ni koro iyara, egbogi nla mbe loke aja, oniruru ohun alaye ni si mbe ni agbala wa. Eniti o ni warapa baba mi wo warapa fun $u$, eniti o ni sobiya baba mi wo sobiya re san, oke aimoye awon adete ni on si so di gbajumo ninu ile wa. Baba mi fi iya je soponna; o fi abuku kan oke-ile; o ba lakuregbe loruko je; inurirun di ero $\underline{\text { ehin; }}$

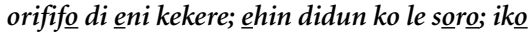
ti sapamo; aran aiya ba es $\underline{\text { se }}$ re soro; jedijedi 
dake minimini; iba nrin tironutironu; igbe orin dorikodo; kuruna nsoku; egbo npose; ifon fa oju ro; otutu si nkanu (Igbo Olodumare, 5).

Yes, Akara-ogun indeed is my name; a medicine man was my father, a babalawo of great renown. A host of charms and myriad medicines filled our house, mysterious potions pulsed in every nook and cranny; from the rafters hung potent prescriptions; and the courtyard buzzed with a myriad living creatures. Those afflicted with epilepsy my father cured of their epilepsy; those suffering from guinea worm my father rid them of their guinea worm; and scores of lepers he made whole and dignified. My father put the small pox through untold affliction; he slandered elephantiasis; he discredited lumbago; colic was debased; headache was demeaned; chronic backache was shamed into silence; the cough was banished; the chest worm was routed; the pile was rendered speechless; the ague was crippled; dysentery was bowed in shame; the craw craw was reduced to tears; skin ulcer was disgraced; the itch was humiliated; the common cold stifled (My translation-The Forest of the Almighty, 60).

Hyperbole and personification advance action and meaning. We know Akara-ogun's father cured, but we also know how he cured and that he cured completely, profoundly. And all this important information is intended to foreground Akara-ogun's own person, his credibility and presumably, his feats, to show he is deserving of his claim to this family prowess, hence name.

The author, Akara-ogun, here delineates a substantive ingredient of his credential-his given name and the source of his renown-the basis for a lengthy and solid oriki which, in a sense, the entire narrative essentially sings. The reading/listening audience is to make no mistake about the author's "Yes, Akara-ogun indeed is my name" proclamation. It is to understand all at once the father's volatile curative powers and the daunting nature of the son's stock which only a measured, energized enumeration such as the above can effectively convey. Yet, the seeming solemnity of the author-narrator's introduction is punctuated halfway through the narrative and truly energized with a panorama of abject, once ghastly enemydiseases which are now verbally deflated beyond recognition. The dehumanizing diseases were not merely removed from their victims' bodies, they were taken on; they were disempowered; they were made to suffer untold humiliation; and then, they were crushed single-handedly! With Fagunwa, an act as simple as curing the sick must resonate with crushing action befitting to both the task and the doer-a good fight as it were in keeping with the reputation and renown of this babalawo. The audience may very well intone its relief for such benevolence on account of the visual and aural impact of the successful depersonification and routing of these mean-spirited diseases and ailments. Here, boasting and exaggeration also combine to effect humor-an essential element in Yoruba storytelling. But alas, this humor loses much of its sound effect in the following English translation of the same passage:

Yes, I am Akara-ogun; my father was a medicine man, a babalawo of great repute. Our house was brimming full of myriad medicines, while mysterious charms pulsed in every corner, and potent prescriptions hung from the rafters. Many weird creatures roamed the courtyard. My father cured the epileptic; the guinea worm- ridden were also cured, and he restored scores of lepers to men and women of dignity. My father punished the smallpox; he humiliated elephantiases; he maligned lumbago; colic was demoted; headache was destroyed; backache became speechless; cough was sent into hiding; chest pain held a rapid dialogue with its legs; pile was thoroughly silenced; ague was made to limp listlessly; dysentery bowed its head; craw craw sobbed bitterly; skin ulcer hissed mournfully; the itch frowned; the common cold sulked pitifully.

An accurate, literal translation of the original passage; however, rid of the boastful tone of the first version, this lean, less dramatic version is devoid of the spirit of fight and poetic justice. Its lackluster tone does not carry the weight of the incredulous babalawo much less his unparalleled curative and combative powers to rid humans of demonic diseases." Punished," "humiliated," "maligned," "demoted," "silenced," "limped listlessly," "sobbed bitterly," "sent into hiding," etc., substituted for the more graphic, forceful, sound-conscious "slandered," "discredited," "debased," "demeaned," "shamed into silence," "banished," "routed," "rendered speechless," "crippled," "bowed in shame," "reduced to tears," "disgraced," "humiliated," and "stifled," pale by comparison. More importantly, the sense and meaning of the passage, which has more to do with Akara-ogun's attempt to confirm his credibility based on solid genealogy than merely chronicling his own father's prowess per se, is diminished.

Another example of Fagunwa's successful integration of sound and meaning, effected this time 
through the device of repetition, likewise illustrates this preoccupation with rhetoric. The conscious circular pattern of repetition through measured and persistent use of recurring, chant-like key verbal phrasing in the following lament for an absent lover illustrates Fagunwa's manipulation of sentiments to arouse the emotions:

O s se! O s se! O s se! Olufe mi ti lo...Tani o dabi olufe mi ninu aiye! Tani o lewwa bi omo na larin omo enia! Tani o le se bi on ti ise fun mi! A! Olufe mi, Olufe mi, Olufe mi owon julo-_lojo ibanuje iwo fun mi layọ; lojo e ekun iwo l'o pa mi lerin; lojo o ibinu iwo l'o tu mi ninu; lojo $\underline{0}$ ija iwo_l'o fun mi ni suru; lọjo iresile iwo ko ko mi; nigbati awon omo araiye ko mi sile iwo ko ko mi; nigbati nwon nbu mi iwo ko bu mi; nigbati nwon ndi rikisisi mo mi iwo ko di mo mi-iwo ni mo fi nse iyi fun awon ore mi, iwo ni mo fi nse forifori fun ojulumo, iwo ni mo fi nse ileri larin awon gbajumo gbogbo. Bi iwo ti nse l'oju mi benni iwo si nse ehin mi pelu...Kil'o ha tun ku fun mi lehin iru eyi! Kil'o ha tun ku fun mi nigbana! Ki iwo lo ki emi joko s'aiye abi nla-Emi kọ. Ijapa ki ilo ki igba ehin re gbe ile, ibiti igbin ba nlo t'on tikarawun ni nlo (Igbo Oludumare, 104-105)

Alas! Alas! Alas! Gone, my love is gone... Who in this world can compare with my love? Whose beauty among humans can compare with my love's beauty? Who can love me the way she love's me? Ah! My love, my true love, my one and only love-in times of sadness you gave me joy; in times of sorrow you turned my tears in laughter; in times of anger you calmed me down; in time of conflict you taught me patience; When I was depressed you did not desert me; when people forsook me, you stood by me; when they joined together in intrigue against me you did not join them-it is you who I flaunt as my wealth to my friends; it is you I uphold as my pride and joy in the midst of respectable company. You were never two-faced with me, You said to my face what you would say behind my back... What else is there that can compare with what you have been to me? What else is there for me to live for without you? What, you gone and I remain in this world? Heaven forbid! The tortoise goes nowhere without its shell; Wherever the snail, there also is its shell (My translation-The Forest of the Almighty, 158-159).

Reminiscent of the incantatory, hypnotic effect of the biblical Old Testament litanies, the lover's last testament engages the audience at a sensory level. The "entertain-edify" twin goals obtain here-the former because the scene is in the context of an otherwise animated story, but it yields precedence to the latter. The two ending proverbs as evidence, the commentary is not merely on the conclusive value of true love. Fagunwa the moralist slips in the morality of honesty, true friendship, good character, the essence of beauty, and the nature of steadfastness in the tortoiseshell/snail-shell imagery and metaphor.

Although Fagunwa did not use the poetic medium or the oriki as did later Yoruba writers, he exploited all the para-linguistic modes of making the language "sing". This is what imbues his prose with that poetic quality Yoruba readers acclaim and celebrate as his distinctiveness. And as Wole Soyinka once put it in response to the cynicism of critics regarding the translatability of Fagunwa, "[t]he essential Fagunwa, as with all truly valid literature, survives the inhibitions of strange tongues and bashful idioms." ${ }^{12}$ In other words, the artistic manipulation of language, a music-prone language at that, the creative use of numerous paralinguistic devices by one preoccupied with the dual authorial intent of edifying and entertaining, speak of a valid literary tradition, indeed a legacy, all too important to confine to a limited local audience and medium. The Fagunwa tradition of melodious storytelling lives on in contemporary Yoruba creative writing as writers seek to achieve the challenge of verbal adroitness the master rhetorician has handed forth. Undoubtedly, much of the music of the ST is lost in the translation process. Yet, in the deft hands of a translator, a good share of the rhythm can be transferred creatively into English to achieve the "sweet" (dun), well told, delightful telling which the author intends.

\section{Pamela J. Olubunmi Smith University of Nebraska, Omaha, USA}

\section{NOTES}

1. As with the characteristic call-response feature of Yoruba choral singing, so too the teller-audience shared experience feature of Yoruba story telling in which the story teller reminds his/her audience of their general participatory/ "helping" role. The phrase can be a formulaic beginning, or a simple plea for alertness, or a "do-your-part-with-gusto" injunction, as in Fagunwa's narrator's example:

The story which follows is a veritable ogidigbo; it is I who will drum it, and you the wise heads who will interpret it... Now I do not want you to dance to my drumming as a mosquito to the deep bembe drums, its legs twitching haphazardly, at loggerheads with the drums. Dance my friends, in harmony, with joy and laughter, that your audience may ring your brow with coins and pave your paths with clothing; 
that men may prostrate before you and women curtsey in sheer pleasure at your dancing. But for a start, if you want this dance to be a success, here are two things I must request of you... (The Forest of a Thousand Daemons, p. 7).

2. Ogboju Ode Ninu Igbo Irunmale, 1948-thirteen reprints. Translated into English as The Forest of a Thousand Daemons, Wole Soyinka, translator, 1968; Igbo Olodumare, 1949-nineteen reprints. Ireke Onibudo, 1949-fourteen reprints since 1956; Irinkerindo Ninu Igbo Elegbeje, 1954-sixteen reprints since 1961; Adiitu Olodumare, 1961-three reprints since 1962. All five novels have been translated into French, but English translations have not fared as well.

3. Yoruba critics-Olubummo, Irele, Bamgboseand non-Yoruba critics Beier, Lindfors.

4. A term coined by Pamela J. Olubunmi Smith from the terms "translation" and "creation" to capture the essence of the multi-lingual creative process African writers go through and the end product of this transcriptive process. Proposed as the theory of translation in modern African literature, it explains the complicated, multifaceted phenomenon of traversing the multilayered linguistic chart of the writer's own mother tongue he/she thinks in and the European language he/she writes in. The transcreative process is that process of self conscious mediation, the writer's straddling the fences of his/her own familiar indigenous tongue and tradition and the alien, learned tongue of the master. African writers are necessarily bilingual, multi-lingual in some cases. "Transcreation" implies that African writers are necessarily translators, a function they perform simultaneously as they create. The simultaneity of the act of translation/creation is the point of convergence between the indigenous cultures (the borrowed material, thoughts and ideas) and (their conversion [in] to) the respective Western cultures/languages-it is the experience of what many have tried to explain in phrases such as "African thought, English/ French/Portuguese words."

5. It is interesting that the thrust of the action of each of Fagunwa's classics takes place in the forest, reflective of Fagunwa's conscious response to the significance of the forest in Yoruba mythology and folklore.

6. Oriki are praise poems/attributive epithets

7. See Bamgbose's pioneer study, The Novels of D.O. Fagunwa. See also Isola's essay, "Features of the Yoruba Novel Today."

8. Things Fall Apart, Chinua Achebe, African Writers Series edition, p. 6.

9. Yoru-Englese is the term I use to describe the language fashioned and used by the urbanized, newly-educated younger generation Yoruba- the Yoruba version of the western yuppy generation with its "hip" consciousness. While it is difficult to determine the percentage of English words that intrude into their Yoruba sentences, nonetheless, it is clear that this slangy, youth lingo will maintain its vibrancy as long as foreign influences continue to impact Yoruba culture and language.

10. See Smith, "D.O. Fagunwa: The Art of Fabulation and Writing Orality." The Literary Griot: International Journal of Black Oral and Literary Studies, Vol. 3, \# 2 (Fall 1991), 1-16.

11. No stranger to Fagunwa's deft manipulation of the Yoruba language, Wole Soyinka, like every Yoruba scholar, has touted Fagunwa, his predecessor and acclaimed influence, as the master of euphony, if ever there was one. Yet this acknowledgment did not prevent Yoruba critics from accusing Soyinka of betraying Fagunwa's voice by creating an overlay of himself in his literal translation of Fagunwa's Ogboju Ode Ninu Igbo Irunmale rather than giving a faithful rendition of the novel. While the criticism does seem valid, the fact remains that Soyinka could not have helped himself. A Yoruba speaker himself, not only is he familiar with the rhythm of the Yoruba language and sound patterns/music inherent in its tonality, he is himself considered a master manipulator of not only the Yoruba language but also the English language. Hence his deft, transcriptive creation rather than a "true and faithful" translation of Fagunwa's Ogboju Ode Ninu Igbo Irunmale, opting " $\mathrm{t}] \mathrm{o}$ preserve the movement and fluidity ...for keeping faith with the author's style and sensibility" (4), and ever so mindful of the euphonic quality implicit in his artistic wizardry.

12. The Forest of a Thousand Daemons, translator's notes, p. 4.

\section{REFERENCES}

Bamgbose, A. (1974): The Novels of D.O. Fagunwa, Benin City: Ethiope.

BeIER, U., ed. (1967): “D.O.Fagunwa: A Yoruba novelist" in Introduction to African Literature, London: Longmans.

EubA, A (1975): “The Interrelationship of Music and Poetry in Yoruba Tradition" in Yoruba Oral Tradition: Poetry in Music, Dance and Drama, Wande Abimbola, ed. Ibadan: Ibadan University Press, pp 471-487.

- (1990): Yoruba Drumming: The Dundun Tradition. Bayreuth African Studies Series, West Germany.

Fagunwa, D.O. (1938): Ogboju Ode Ninu Igbo Irunmale, CMS Bookshop, Lagos; Nelson, 1950.

- (1949): Igbo Olodumare, Nelson.

IDowu, E. B. (1962): Olodumare: God in Yoruba Belief. London: Longmans. 
Izevbaye, D. S. (1995): "Fagunwa's Brave Spirit: A Study of the Contexts of a Literary Reputation" in Language In Nigeria: Essays in Honour of Ayo Bamgbose, Kola Owolabi, ed., Ibadan: Group Publishers, pp. 250-275.

Okedij, O. (1969): Aja L'o Leru. Ikeja: Longman.

Sмith, P. J. O. (trans.) (1984): The Forest of the Almighty. Unpublished Ph.D. dissertation, University of Washington.: "D.O. Fagunwa: The Art of Fabulation and Writing Orality." The Literary Griot: International Journal of Black Oral and Literary Studies. Vol. 3, \#2 (Fall 1991), 1-16.

SoYINKA, W. (trans.) (1968): The Forest of a Thousand Daemons. Nelson. 